\title{
The conception of fashion products for children: reflections on safety parameters
}

\author{
Prete, Lígia Gomes Pereira ${ }^{1}$; Emidio, Lucimar de Fátima Bilmaia ${ }^{2}$ : Martins, Suzana Barreto ${ }^{3}$ \\ ${ }^{1}$ Esp.,Design Department, Londrina State University, ligiaprete@hotmail.com Paraná, Brazil \\ ${ }^{2}$ Msc, Design Department, Londrina State University, lucimar@uel.br, Paraná, Brazil \\ ${ }_{3}^{3}$ Ph.D, Design Department, Londrina State University, suzanabarreto@onda.com.br Paraná, Brazil
}

\begin{abstract}
The purpose of this study is to reflect on safety requirements for children's clothing, based on the standardization proposed by the ABNT (Technical Standardization Brazilian Association). Bibliographic research and case studies were considered on writing this work. We also discuss the importance of adding other safety requirements to the current standardization, as well as the increasing of the actual age range specified by the ABNT, following the children's clothing safety standardizations in Portugal and the United States, also stated here.
\end{abstract}

Keywords: children's clothing, ergonomics, standardization

\section{Introduction}

According to the 2008 World Report on Children's and Teenager's Accident Prevention, published by the World Health Organization and the UNICEF, 830,000 children die from accidents every year, around the world.

As stated by the Safe Kids Organization, accidents, or unintentional injuries, represent the main cause of death of children between 1 and 14, in Brazil. A total of over 5,000 children die and around 137,000 are hospitalized every year, according to the Health Ministry, and so it becomes a matter of public health. Statistics show that for every dead child, four children are permanently injured, and this will probably cause emotional, social and financial consequences to their families and to the society as a whole. Almost R\$ 63 million are spent by the Public Health in Brazil. (www.criancasegura.org.br).

Studies show that at least $90 \%$ of those traumas could have been avoided if prevention measures had been taken. ${ }^{1}$

\footnotetext{
${ }^{1}$ Source: http://www.criancasegura.org.br/dados_acidentes.asp
}

Therefore, based on those statistics, designing children's clothing that fulfill safety requirements is necessary, to avoid accidents and assure their wellbeing. Accidents caused by buttons, charms, pompoms, drawstrings, and other decorations are very common and can be very severe in many cases.

Accidents involving children occur because adults who are responsible for taking care of them usually fail to recognize the dangers in many situations. That is why children's clothing manufacturers should, while designing the garments, think about safety. Hence, most products destined to this public ought to obey the safety rules, determined by law. This is the case with toys, which must have the Metrology, Standardization and Industrial Quality National Institute (INMETRO) certificate indicating the age range ${ }^{2}$,among other important data.

Until the present time, there are no laws to ensure safety and physical integrity for children between the ages of 0 and 14, regarding their exposure to

\footnotetext{
${ }^{2}$.More info:

http://www.inmetro.gov.br/infotec/publicacoes/cartilhas/criancaSe gura/crianca_segura.pdf
} 
determined clothing products. There is no regulation to penalize manufacturers who do not consider preventive measures. The standardization project, proposed by the ABNT (with no standardization value yet) NBR 17:700-03-004 referring to "Children's clothing - Safety and Performance" when approved will not be mandatory, leaving the manufacturer free to comply it or not. However, it is a matter of ethics and principles to think about the user's safety. Every product should be safe; especially those destined to children under 14 .

A complete and efficient standardization is necessary to prevent children from being exposed to potentially dangerous elements that can risk their physical integrity, such as inadequate sized buttons, drawstrings and other attachments, long strings and easily flammable garments.

In this context, the present study aims at reflecting about the referred standardization and to bring up the importance of including other safety requirements to the rule, and to increase its age range.

\section{Children's Clothing: A Brief Context}

Ariès [1] states that the so called Age of Enlightenment ${ }^{3}$, generated a new being: the child, after Jean-Jacques Rousseau's development of modern political, sociological and educational thoughts. For the philosopher, the infant's needs and desires are different from those of a grownup. In his speeches, he claimed that they could not be treated as small adults. With his ideas, children began having singularities, as their own space, rules, shape and behavior.

According to Ariès [2]: Before the $13^{\text {th }}$ Century [...] the indifference towards children and their features is clear not just in paintings: the clothes they wore at the time show how little the infancy was distinguished in real life. As soon as the babies left their diapers, a piece of clothing that was wrapped around their body, the child was dressed up exactly like the men and women in the same conditions.

Until the $18^{\text {th }}$ Century, infancy was not understood as a period of discovering and experimentation, where the child was seen as having a puerile innocence, with its particular way of seeing, feeling and thinking. As soon as they were 5, 6 or 7

\footnotetext{
${ }^{3} 18^{\text {th }}$ Century, before the French Revolution
}

children were considered old enough to be able to survive without their mother's or any adult's care. So, they were ready to join the grownup men and women and start producing something, learning a job or executing everyday chores.

What we understand as childhood in our modern Western society was not a reality in the past decades. This new thought referring to infancy has widely influenced fashion. In the past, children were seen as miniature adults and so they were dressed up that way, behaved in a similar way, wore the same clothes and imitated their habits. After Rousseau's new conception of childhood, the youngsters have achieved their space and changed their clothing as well, valuing more adequate shapes, materials and fittings. Rousseau said that the best for children was to wear smocks most of the time, and they should be made of light colored soft fabrics.

That freedom in children's clothing lasted until 1860. After that, children's clothing became uncomfortable again, and again they looked like the adult's. It is worth to point out that during that period, the official fashion was the sailor suit, for boys and girls, with a few changes. During the $20^{\text {th }}$ Century, especially the first two decades, we can see a modification that ensured a little more freedom and comfort for the coming years. The clothes were loosened and shortened, so they were more adequate for the children's movements - they were now freer to run, jump, play and practice all typical childhood activities.

Nowadays we see a bigger concern in adapting fashion products according to the people who are going to wear them.

The development of a fashion product is a process that should follow some steps, common to any kind of public; adults, teenagers or children.

According to Montemezzo [3], the development of a fashion product starts by planning, which includes the perception of the market and discovery of new opportunities, definition and analyzes of marketing strategies, development, production, distribution and sales, and the chronology definition. The second stage is about the project research and specifications, where the consumer will be analyzed, the fashion contents, available material and technologies will be explored, and the project purposes will be defined. The third stage starts with a conceptual choice, which means, the generation of concepts and the definition of importance and style.

The next stage is the generation of configuration alternatives, fitting shape and principles. Once these 
stages are defined, we can now go on to the development of the product itself and manufacturing the prototype. At this point, correction and adequacy of the product whether it is usable are considered, the pattern and cut planning and the fitting graduation are performed. The final stage is the production of these pieces, the market release and the sales.

In regard to the development of fashion products for children's clothing, first of all, one must consider that childhood is a very particular period of time. The relevant activities must be analyzed so the parameters are established in the creation of clothes for people between 0 and 14 .

The fashion product must have ergonomic features, of usability and safety to make a good relation with the body possible. The child has naturally more disposition to practice activities that require wide movements and he or she will need clothes that are suited for more dynamic activities. The garment should be adequate and comfortable and the opening and closing mechanisms should be simplified. The other attachments should be safe, to avoid accidents and ensure that those children cannot choke, aspirate, or swallow those attachments.

As defined by Martins [4]: usability represents the interface that enables the effective utilization of the products. They should be friendly and joyful to use, especially clothing articles.

Usability indicators are directly related to the easy management, which, in its turn, determines if it can be worn, its usability: how to dress up, to undress, how to easily access the functional attachments, either opening or closing the apparel.

According to Nielsen, Staton and Hordan [4, p.3] usability has other basic principles, which are:

- Satisfaction (wearing the system must be pleasant);

- $\quad$ Ability to learn (the system must be easily understandable);

- Memory capacity (the system must enable the user to easily remember how to get back to it after some time, without having to learn the process all over again);

- Compatibility with the user (the system must work according to the user's knowledge of the world);

- User's control (maximize the control over the product's actions);

- Visual clearness (information must be presented in order to be quickly and easily understood).
The conception of children's fashion products must be guided by safety parameters that can avoid possible accidents with its elements.

Therefore, we can infer that usability is one of the main factors while designing a fashion product, especially those intended for children, due to their limited perception of the world.

\section{The child's body structure as a parameter to adequate children's clothing}

Infancy is a moment of learning, experimenting. It is the time when the human being has the most active routine. At this stage, the child is developing a series of motor and mental abilities; the child is usually practicing activities that consume a lot of energy, he or she is preparing the muscles by executing wide movements. All the tasks are entertaining with the purpose of developing the body and mind.

In general, children have their gravitational center located on the upper part of the body, especially babies and younger children. The younger the child the nearer to the head the gravitational center is.

While the body develops and grows, the gravitational center dislocates down to the torso. This is why smaller children, beginning to grow up, are more inclined to fall.

At this stage, their bones are still in the hardening process, which means that they are growing lengthwise, and this will only be completed towards the end of the adolescence. The fullest mineral deposition will occur between the ages of 20 and 30 . That way, children are very susceptible to fractures, because the long bones normally reach $80 \%$ of their final length at the age of 7 , while its mineral content is only $40 \%$ of its final level ${ }^{4}$.

The bones grow in length before they get strong. Besides, the risk of fractures is high because after a phase of quick growth, children must learn how to manage their new posture, and the soft tissues must develop to adapt to the new dimensions.

The child's fine coordination is not completely developed and this will depend on how each individual is stimulated. However, regarding the fundamental motor skills, for Gallahue and Ozmuz

\footnotetext{
4 .Source: http://design-ergonomic.blogspot.com/2006/06/designpara-as-criancas.html
} 
[5], most children possess a development potential that leads them to a mature stage at the age of 6 .

Among other aspects to be approached relating the infant body structure, the sense of touch must be considered in order to enlighten the importance of the materials used in manufacturing the products. Children, especially those under 4 , have thinner skin than older ones and adults, due to its immature structure, so they burn quicker and with lower temperatures.

A three-year-old exposed to tap's hot water at 60degree Celsius for three seconds will suffer a severe three-degree-burn, a lesion that requires hospitalization and skin transplant. Also, because having such a fragile and sensitive skin, children are more disposed to dermatitis.

At this stage, children under 4 have less control of the environment and may not be able to escape dangerous burning, drowning or choking situations that can risk their lives.

Children's body structure must be studied to adequate their clothing according to their capacities, abilities and limitations [6]. Children have a more delicate physiology and a more limited understanding of their environment, so they tend to perform activities that are potentially dangerous to their physical integrity. Children's clothing should be thought to avoid those lesions.

Objects that can strangle must be re-evaluated and re-thought, as well as the use of garments that can easily spread flames. Small "mistakes" in fashion products conceived for children can cause serious damages to their physical integrity.

\section{Comparative reflection referring to the safety aspects established for children's clothing}

Nowadays, in Brazil, a standardization proposition is waiting for approval. This subject matter was elaborated by the ABNT and relates to children's clothing safety and performance, the NBR 17: 700-03-004. However, after analyzing such proposition, one can observe that some safety aspects are missing.

The standardization mentions subjects such as the preservation of the color and the endurance of the fabrics, the deterioration and traction rates, among others, but there is little discussion on safety aspects. This rule has the following safety requirements:
1. Clothes for children between 0 and 2 must not have broaches, attachments or decorations that can be easily swallowed;

2. Clothes for children between 0 and 2 must not have drawstrings for the hood or the waist;

3. Clothes for children over 2 must avoid drawstrings for the hood or waist, because they can cause strangulation. In case they are used, an alert must be placed on the label, tag or packaging;

4. There must be an inside protection for zippers, except in jackets or where the invisible zipper is used;

5. Zipper pulls must be protected always, to avoid skin contact;

6. Velcro must be correctly fixed, the soft part facing the skin;

7. Velcro must be correctly cut, the borders should be rounded or beveled;

8. Buttons and attachments must not have cutting edges, according to ABNT NBR NM 300-1 (item 5.8);

9. The clothes must be checked, to look for residues and broken needles;

10. Fabrics used for lining underwear should be anti-allergic.

According to the NPO (Non-Profit Organization) Safe Child [7], children are more exposed to lesions than adults, because they are in learning and growing processes. Briefly, each stage of childhood presents different lesion risks, as follows:

1. Lesion risk factors for children between 0 and 4:

- The lack of ability to recognize and understand dangers;

- The body coordination is still developing;

- The tendency to imitate the adults;

- The limited ability to react quickly and accurately.

2. Lesion risk factors for children between 5 and 14:

- The greater experience to undertake the chores of an adult;

- The greater interest in danger;

- The greater interest in taking chances; 
- The disposition to challenge each other and act dangerously;

- The greater amount of free time without the supervision of an adult.

Among other matters referring to infancy, we can still point out the natural levels of development.

According to the NPO Safe Child (2010) the biological systems are still growing and developing during the childhood: the skin is thin and delicate, the internal organs (lungs, heart, liver, etc) are yet immature, the skeleton is fragile and the skull is not completely closed, thus far. The natural protection barriers give fewer defenses to children, when comparing to adults. As a consequence, the skin is more sensitive to lesions caused by burnings, cuts and wounds $[\ldots]$. [7, p.5] [...] children do not recognize the relations between cause and effect until they are 5 or older

[...]. the lack of experience and the mental ability which is still developing in children also affect their perception of danger and the prediction of what kind of lesion is related to the risk. $[7$, p.6].

Besides that, children "especially those under 3, explore things by putting them in the mouth. This natural tendency puts them in great choking risk situations [... and thermal burns" [7, p.7].

This way, we infer that the propositions made by the ABNT do not take into consideration the fact that children over 2 also need special care in accident prevention due to clothing components (fabrics, fitting and attachments) if inadequate or badly projected for the final user.

This concern relating safety requirements for children's clothing has been discussed in developed countries for some time.

Countries like the United States and Portugal, among others (especially those in the European Community) have children's clothing regulations that are already contributing to the children's safety and welfare.

For instance, in 2005, in Portugal, the law NP EN 14682:2005 came into force. It specifies safety requirements for fix and run through drawstrings for children's clothing, including costumes and ski equipment up to size 14. This is a mandatory standardization, by the order of the General Product Safety Directive (GPSD - Directive 2001/95/EC), and it also indicates that a Risk Evaluation should be performed in every style of children's clothing, considering the destination of the product (the user's age). This standardization was created by Anabela Gonçalves, the division director of the Consumer Testing Services, "due to an alarming number of wounds and fatalities involving children under 14"

Thus, the European Community decided to establish rules for the children's clothing industries in order to reduce the risks of strangling or other injuries. The rules are divided according to age groups, from 0 to 7 and from 7 to 14 years-old.

Some of them are:

- It is forbidden, for both age groups, the use of either fix or run through drawstrings at the back of the apparel;

- The length of the fix or run through drawstrings must be limited, according to its position on the apparel;

- For children under 7, the use of functional or decorative drawstrings on the neck area or hood is forbidden;

- For children over 7, the use of elastic functional or decorative drawstrings on the neck area or hood is forbidden;

In the United States, Abe Bergman, a pediatrician, worked hard for the approval of the Federal Law concerning Flammable Fabrics, in 1977, and due to his efforts a regulation on children's sleepwear was created. This law (Children's Sleepwear Regulations, 16 C.F.R. Parts 1615 \& $1616)^{6}$, which is part of the Consumer Federal Regulation, determines that all sleepwear should be submitted to flammability resistance tests and must have tight-fitting specifications, according to each age. The rules include all pajamas that are sized above 9 months and up to size 14, as well as nightgowns, robes or loungewear, or those suitable to sleep or related to sleeping.

Tight-fitting sleepwear must obey the following rules:

\footnotetext{
${ }^{5}$ Source: http://www.pt.sgs.com)pt obrigatoriedade_da_seguranca_do_vestuario_infantil_sgs_apoia_i ndustria_textil_pt

${ }^{6}$.Source: http://www.cpsc.gov/businfo/regsumsleepwear.pdf
} 
1. Not exceed the maximum dimensions specified in the regulations for the chest, waist, seat, upper arm, thigh, wrist, or ankle;

2. Have no fabric ornament or trim, such as lace or ribbon, which extends more the $1 / 4$ inch from the point at which it is attached to the garment;

3. Have sleeves that taper from the shoulders to the ends of the sleeves;

4. Have pant legs that taper from the thighs to the ends of the pant legs;

5. If they are 1-piece, taper from the chest down to the waist and from the seat up to the waist;

6. If they are 2-piece,

a) Have an upper piece that tapers from the chest to the bottom of the piece,

b) If the upper piece has fastenings, have the lowest fastening located within 6 inches of the bottom of the piece, and

c) Have a lower piece that tapers from the seat to the top of the piece;

7. Bear a permanent label stating size of garment;

8. Bear a hang tag alerting buyers that the garments are not flame-resistant and should be worn snug fitting because loose-fitting garments are more likely to catch fire;

9. Comply with all of the flammability requirements for clothing textiles.

Besides the above requirements, children's sleepwear must:

- Have a permanent label with instructions on how to take care of the garment to protect it from chemicals or other treatments that can reduce its flame resistance;

- Have a permanent label with a unit identification (number, letter, date, or combination thereof) so manufacturers can track the garment's associated fabric and garment production lots in the event of recall;

- Manufacturers and importers must maintain written records as specified in the regulations.

If a products fails in the flammability or in the tight-fitting test, it will be rejected and those units can be destroyed, exported (only with CPSC -
Consumer Product Safety Commission), or reworked to improve their flammability resistance.

It is important to notice that these rules are being followed, and in those countries accidents affecting children's clothing are decreasing.

\section{Reports regarding domestic accidents with clothing: case studies}

Considering our goals, this study was based on bibliographic research and on a case study, which according to Yin [8], is an empirical investigation which examines a contemporary phenomenon inside the real life context. This will benefit the previous development of theoretical propositions leading to the data collection and analysis.

The case study enabled us to register health professional's statements and records, indicating that the so called domestic accidents involving children are one of the biggest causes of hospital and ER attendance and hospitalization. 160 cases of this kind were attended to, only in the Evangelic Hospital, in Londrina, between April and Jun, 2010.

According Gilberto Berg, who is a specialist nurse in pediatrics and preventive medicine, and has worked in Londrina, in the north of Paraná State for the past 15 years, accidents affecting children and elements of clothing are very common ${ }^{7}$. The nurse remembers having attended a number of cases in hospital ERs where he worked throughout his career. He mentioned a specific one, when a 3-month-old fell asleep in his baby-seat and the drawstring of his hood was caught in the chair. This caused a serious lesion on his neck. The child came into the ER with a skin lesion, indicating he was being strangled. In some cases, the trachea (windpipe) can suffer a lesion, and this could be fatal.

The interviewed also quoted that it is very common to attend small children, especially those between 1 and 3, who go to the ER with their ears or noses obstructed because they introduced buttons or beads in them.

Reports that were broadcasted all over the world were investigated, and we would like to emphasize one. In the city of Rufino, Argentina, in April, 2010, three-year-old boy Geremias Cabezas suffered a terrible accident while playing at his nursery school. His hood drawstring got caught in the sliding board

${ }^{7}$ Gilberto was interview on August 25, 2010 
while he was playing and it strangled him, causing his death ${ }^{8}$.

Reports of accidents with clothing elements such as buttons are, for example, very common:

"At the time he was three-years-old, he swallowed a 50 cent coin, that was in 2007.

Last year, in 2009, he swallowed the button from his jeans shorts." 9

"She was 10-months-old, and while I was shooting some pictures of Luana I "thought" I saw something inside her mouth; I looked closer but didn't see anything. After a while I noticed there was a huge button missing from her dress! At night, I found the button in her diaper, in the middle of the poop!" 10

According to studies performed by health professionals Christine B.G. Martins and Selma M. Andrade, there were 434 cases of accidents involving foreign bodies (penetration in a natural opening, inhalation or ingestion) involving children under 15, in all hospital and emergency services in Londrina, in 2001. The penetration of foreign bodies in natural openings (eyes, noses and ears) represent $94 \%$ of the attendance, or 408 cases $^{11}$. Yet according to the research, the age range that holds most cases is between 1 and 3 (46\%). The study demonstrates that beads, buttons, bottle caps, grains and seeds are the most frequent agents causing those accidents.

According to the researchers, the lack of detailed registers on the agents responsible for accidents "awakens for the need to improve the records and the quality of information" [9, p. 1988]. Gilberto states that unfortunately the registered information of attendance, available in public hospitals, does not indicate which agents are responsible for choking, ingestion or inhalation accidents with a foreign body.

\footnotetext{
${ }^{8}$ The Geremias Cabezas case was widely broadcasted. Source: http://momento24.com/en/2010/04/16/a-3-year-old-died-hangedin-a-nursey-school-in-rufino/

9 Social Assistant Terezinha Lisieux's statement to the website notapajos.com, affiliated to globo.com, on April 28, 2010.

10 Source:

http://meumundoenadamaisevelly.wordpress.com/2010/05/27/atest ado-de-incompetencia-de-mae/

${ }^{11}$ Followed by the inhalation and ingestion of food $(2.8 \%)$, the inhalation of other objects $(2.5 \%)$ and the inhalation of gastric fluids $(0.7 \%)$.
}

In burning accidents, cases are worsened by easily flammable garments and fabrics, and that is another problem. Burns are the second cause of children hospitalization and one of the main reasons for their deaths ${ }^{12}$. It is one of the most painful and devastating lesions that a human being can endure and survive. The interviewed nurse emphasized that he has already attended to many cases of children's injuries caused by burns. He points out that these cases are usually serious, because the injuries are extensive and their skin is more fragile. Gilberto taught that in most cases burn accidents with children under one-year-old occur because of the parents' or caretakers' negligence. Burning accidents with children between one and four usually occur in the kitchen, where the children, out of curiosity, pull the objects off the table or the pans off the stove, and are therefore scalded.

He explains that scalding accidents are as a rule very dangerous, "because the liquid flows and reaches a bigger part of the body." If the burn reaches the torso, it is even worse because of the risk of dehydration and it can even cause lesions in internal organs. For older children, between 5 and 6, accidents mostly happen because they are curious to handle fire.

Many times burning lesions are worsened by the garments used at the time of the accident. They melt and stick to the skin. Flammable garments are a threat when exposed to high temperatures. When the textile adheres to a lesion, a procedure called mechanical debridement is performed. It is the process of removing nonliving tissue from pressure burns, using saline-moistened dressing, forceps, scalpels, scissors (and other surgical instruments). This procedure is extremely painful and traumatic because, sometimes, the dressing can adhere to living as well as nonliving tissue, so the physician will end up removing more than one layer of the skin. This will eventually require a skin transplant.

\section{Final considerations}

Introducing preventive information to the society in general can make it possible to reduce the number of domestic accidents.

\footnotetext{
12 .Source:

http://www.criancasegura.org.br/relacao dos acidentes.asp
} 
Martins and Andrade [9] state that creating and implementing a protocol to attend children who are victims of accidents, and training the professionals to determine the circumstances of those accidents can contribute to the epidemic knowledge of this important cause of mortality, leading to better planning actions to control and prevent them. [...] The results of the research make us believe that actions and specific orientation to parents and caretakers make it possible to greatly reduce the number of accidents caused by a foreign body. By knowing which agents are responsible for accidents with a foreign body will allow the immediate action, removing them from the child's environment, hence avoiding unnecessary wounds and lesions.

The authors also believe that education on different stages of children's development and the potential hazards they are exposed to are essential in this context [9, p. 1988]. Besides, they state that buttons, grains, seeds, coins, bottle taps, among many other objects, must be kept away from children. As a prevention measure related to clothing items, they express the importance of not using any kind of drawstrings, ribbons, laces or any other similar attachment in children's clothing, as well as not using garments and fabrics that are not flame resistant.

\section{References}

[1] Gonçalves, E.; Ribeirão F., J. A. Aspectos Ergonômicos evolução do vestuário infantil. In: $2^{\circ}$ Encuentro Latino Americano de Diseño, Anais... Buenos Aires, 2007.

[2] Ariès, Philippe. História Social da Criança e da Família. Rio de Janeiro: Afiliada,1981. 280 p.

[3] Montemezzo, Maria Celeste F. S. Aspectos ergonômicos no projeto de produto de moda. In: $14^{\circ}$ Congresso Brasileiro de Ergonomia, ABERGO 2006, Anais...Curitiba, 2006.

[4] Martins, Suzana Barreto. Ergonomia e Usabilidade: princípios para o projeto de produtos de moda e vestuário. In: $14^{\circ}$ Congresso Brasileiro de Ergonomia, ABERGO 2006, Anais...Curitiba, 2006.

[5] Pellegrini, Ana Maria et al. Desenvolvendo a coordenação motora no ensino fundamental. Disponível em $<$ http://www.unesp.br/prograd/PDFNE2003/Desenvolvendo $\%$ $20 \mathrm{a} \% 20$ coordenacao $\% 20$ motora.pdf $>$ Acesso em 12 de agosto de 2010 .

[6] Iida, Itiro. Ergonomia: projeto e produção. São Paulo: Edgard Blücher, 2005, 2a edição. 632 p.

[7] Guia da Criança Segura em Casa. Elaborado por Safe Kids Worldwide, traduzido e adaptado pela Criança Segura Coligação Curitiba. Curitiba, 2005.

[8] Yin, Robert K. Estudo de caso: planejamento e métodos. Porto Alegre: Bookman, 2001. 2.ed.

[9] Martins, C. B. G.; Andrade, S. M.. Acidentes com corpo estranho em menores de 15 anos: análise epidemiológica dos atendimentos em pronto-socorro, internações e óbitos.
Based on this study, we emphasize the awareness and importance of an accurate study relating safety, while developing children's clothing products. Children's clothing designers and manufacturers should be conscious that small adjustments and corrections in the conception of the garments can avoid serious lesions and even the death of a child, in case of an accident. Parents, in their turn, should not buy products that are potentially hazardous for children.

In reference to the standardization proposed by the ABNT, mentioned above, one notices it does not meet the safety requirements to ensure the physical integrity of fashion consumers under 14 , because it does not take into consideration some actions that could avoid accidents with some of the clothing elements. According to the approach brought by this study, one must consider that children above 2 are also victims in accidents caused by clothing.

Society can mobilize by speaking up to form the rules set by the $\mathrm{ABNT}$ and even requiring government resolutions that ensure manufacturers to provide safe products for children's clothing, referring to accident prevention. These accidents can be avoided when the products are conceived and safety factors are considered.

Caderno da Saúde Pública, Rio de Janeiro, v. 24, n.9, p.19831990, set. 2008 .

\section{Researched websites:}

Associação para a promoção da segurança infantil - APSI. Disponível em $<$ http://www.apsi.org.pt/index.php $>$ Acesso em 19 de agosto de 2010.

Children's Clothing Regulations. Disponível em

$<$ http://www.apparelandfootwear.org/LegislativeTradeNews/Child rensClothingRegulations .asp $>$ Acesso em 18 de maio de 2010.

Children's Sleepwear Regulations1, 16 C.F.R. Parts 1615 \& 1616. Disponível em

$<$ http://www.cpsc.gov/businfo/regsumsleepwear.pdf $>$ Acesso em 11 de maio de 2010.

Criança Segura - Safe Kids Brasil. Disponível em $<$ http://www.criancasegura.org.br $>$ Acesso em 20 de agosto de 2010.

Novos padrões para vestuário em discussão na ABNT. Disponível em $<$

http://www.abnt.org.br/m5.asp? cod noticia=153\&cod pagina $=965>$ Acesso em 11 de maio de 2010 .

Obrigatoriedade da Segurança do Vestuário Infantil - SGS apoia Indústria Têxtil. Disponível em<http://www.pt.sgs.com/pt/

obrigatoriedade_da_seguranca_do_vestuario_infantil_sgs_apoia_i ndustria textil pt?viewId $=741>$ Acesso em 11 de maio de 2010.

Relatório de avaliação sobre segurança infantil 2009/ Portugal. Disponível em 
$<\quad$ http://www.apsi.org.pt/24/portugal_brochura_16pgs.pdf $>$ Acesso em 13 de maio de 2010

Segurança do vestuário infantil. Disponível em
$<$ http://www.europarl.europa.eu/sides/getDoc.do?pubRef=$/ / \mathrm{EP} / / \mathrm{TEXT}+\mathrm{WQ}+\mathrm{E}-2009-6580+0+\mathrm{DOC}+\mathrm{XML}+\mathrm{V} 0 / / \mathrm{PT}>$ Acesso em 9 de maio de 2010 . 